\title{
Drop out prediction in sport centres. Definition of models and reproducibility Predicción de bajas de clients en centros deportivos. Definición de modelos y reproducibilidad

\author{
**Iván Clavel San Emeterio, *Jorge García-Unanue, , **Eliseo Iglesias-Soler, *Leonor Gallardo, ***José Luis Felipe
} *Universidad de Castilla-La Mancha (España), **Universidade da Coruña (España), ***Universidad Europea de Madrid (España)
}

\begin{abstract}
Purpose: One of the main problems detected in the sport centre field is abandonment of physical activity by members. The aim of this estudy is to evaluate the reproducibility of predictive models of abandonment in sports centres, based on information collected through access control and the Customer Relationship Management system. Method: Monthly data corresponding to the actual behaviour of of two sport centres in Spain were recorded over the course of one year (12,545 members). Based on these variables, two predictive models were designed using the absence or permanence in the centre as an independent variable. Subsequently, the regression formula obtained was applied on all members of the same sports centres a year later (12,986 members), checking the effectiveness and reproducibility of the model. Results:. Logistic regression models based on customer historical behaviour were useful to predict abandonment. The effectiveness of the models was around 70\% a year after. Conclusions: The segmentation of users based on the likelihood of drop out and the identification of behaviour variables that predict such drop out and the confirmation of the effectiveness of the predictive model, can help to optimize the design of loyalty strategies to prevent the abandonment in sport centres. Keywords: Fitness, Loyalty, Physical Activity Promotion, Behaviour, Logistic Regression.
\end{abstract}

Resumen. Objetivo: El abandono de la práctica deportiva por parte de clientes en centros deportivos es uno de los principals problemas en el sector. El objetivo de este estudio es evaluar la reproducibilidad de modelos predictivo de abandono en centros deportivos, basados en información recogida a través del control de accesos y el sistema Customer Relationship Management. Método: Se recopiló comportamientos mensuales de los clientes de dos centros deportivos en España durante un año (12,545 members). En base a dichas variables se diseñaron dos modelos predictivos utilizando la baja o permanencia en el centro como variable independiente. Posteriormente, se aplicó la formula de regression obtenida sobre todos los miembros de los mismos centros deportivos un año después (12,986 members), comprobando la efectividad y reproducibilidad del modelo. Resultados: Las estimaciones de regression logística fueron útiles para predecir el abandon en los centros deportivos. Además, reproduciendo el mismo modelos en una muestra diferente se consiguió aproximadamente un 70\% de efectividad. Conclusiones: La segmentación de usuarios en base a la probabilidad de baja y la identificación de variables predictivas de dicha baja pueden optimizar el diseño de estrategias de prevención de abanadono en centros deportivos. Palabras clave: Fitness, Fidelización, Promoción Actividad Física, Comportamiento, Regresión Logística.

\section{Introduction}

Sport has established itself as a clear health promoter and a way of spending leisure time in the current society. This means that in countries like Spain, an exponential increase in sport participants over recent years has taken place(European Commission, 2014; García Ferrando \& Llopis, 2011; IHRSA, 2014). Agreat part of this development is based on the increment in infrastructure of both fitness and wellness centres, each time of a higher quality orientated towards satisfying user's demands. Europe Active (2015) reports that in 2014 fitness and wellness centres in European countries had 50.1 million members and a membership penetration rate of $7.4 \%$ in 2014. In 2018, 62.2 millions users and a 7.8\% penetration ratio in Europe are quantified (Europe Active, 2019). Worldwide, IRSHA (2019) quantifies a total of 183 millions. In Spain, an average of 3,037 members per club and a total of 4,350 clubs have been calculated (IRSHA \& Universidad de Alcalá, 2018). However, the fitness industry faces a major challenge: member loyalty and the high level of dropout rates (Hillsdon, 2001; IHRSA, 2012; MacIntosh \& Law 2015; McCarthy, 2004). Several studies show that more than $50 \%$ of those enrolled in an exercise programme will abandon the activity before the end of the year (Bedford, 2009; Dishman, Sallis \& Orenstein, 1985; Hillsdon, 2001; IRHSA, 2012; MacIntosh \& Law 2015). This is particularly important in the case of people inscribed in fitness centres, according to recent

Fecha recepción: 08-03-19. Fecha de aceptación: 08-07-19

Jorge García-Unanue

jorge.garciaunanue@uclm.es studies. Thus, Gallardo, Rodríguez-Cañamero, HernandoBarrio and Peñas (2016) indicate that 70\% of those that enrol in a fitness centre leave before the end of the first year, while Sperandei, Vieira and Reis (2016) prove that there is only a $3.7 \%$ probability that a member will stay for more than a year in a fitness centre. More recent studies suggest this dropout ratio is related to the perception of improvements in physical condition. They explain that the registration to a sports centre is associated with the improvement of parameters related with physical condition, and the fact of not perceiving improvements in a prudential time (less than a year), causes the drop-out (Gjestvang, Stensrud \& Haakstad, 2019). In this sense, Rodríguez-Cañamero, GarcíaUnanue, Felipe, Sánchez-Sánchez and Gallardo (2019) demonstrate how the majority of users of sports centres register to improve their physical condition, and of those who register for other reasons (such as leisure), continue at the centre to stay in good physical condition. Veiga, ValcarceTorrente, King-Clavero and de la Cámara $(2018,2019)$ show that weight loss is the third most representative trend in the fitness sector in 2018, rising from sixth position occupied in 2017. On the other hand, most of the users choose the gym by proximity (Life Fitness, 2018, Rodríguez-Cañamero et al., 2019), although this choice is one of the factors that in the medium and long term generate more dissatisfaction for users (Rodríguez -Cañamero et al., 2019).

Furthermore, this sector has experienced a large increase in competitiveness, marked by polarization and the development of business models such as low-cost (García, Gálvez \& Bernal, 2015; García-Fernández, Gálvez-Ruíz, Fernández-Gavira, Vélez-Colón, Pitts \& Bernal-García, 2018; 
Valcarce, López \& García-Fernández 2019), or more recently the boutique centres (Valcarce, Cordeiro \& García-Fernández, 2017). It is very likely that low-cost have favored the entry of new users who had not previously been members in any sports centre, convinced by the price, which leads to a shortterm motivation but does not guarantees for a long-term stay (García -Fernández, Gálvez-Ruíz, Fernández-Gavira et al., 2018). Finally, studies in the sport sector suggest that greater variety of prices and services are related to higher rates of repentance (Pérez-González, García-Unanue, SánchezSánchez, Sánchez-Burón \& Burillo, 2018. However, this variety that is constantly growing in the fitness sector (EstradaMarcén, Sanz Gonzalo, Casterad Seral, Simón Grima \& Roso Moliner, 2019).

Therefore, fitness centres star from very unfavorable conditions for retention and loyalty, which represents a problem from a double perspective. On one hand, the viability and sustainability of the fitness centre market (Theodorakis, Howat, Ko and Avourdiadou, 2014), which is becoming a main pillar for sports practice promotion. On the other hand, as current physical activity promoters, as they are the most popular places to practice sport in cities (IRSHA, 2010; Sperandei et al., 2016). Therefore, although abandonment of programmes in fitness centres may mean the start of a new physical activity programme, Gallardo et al. (2016) suggest that between $19 \%$ and $24 \%$ of the users stop practising sport after dropping out of a sport centre.

Literature clearly identifies customer loyalty as an effective tool to prevent dropouts. However, there is no consensus in literature regarding measurement and definition of loyalty construct. In this way, customer loyalty can be analysed from different perspectives (Dimitriades, 2006; Söderlund, 2006).

The attitudinal approach approximates the loyalty measurement through behavioural intentions, which has been conceptualized as indicators that show what customers are going to do in the future in terms of recommending the centre and demonstrating positive repurchase behaviours (Brady \& Robertson, 2001; Caruana, 2002; Clemes, Gan \& Ren, 2011; Delgado, 2004; Dick \& Basu, 1994; Lutz, 1991; Oliver, 1999; Zeithaml, Berry \& Parasuraman, 1996; Zeithaml, Bitner \& Gremler, 2009). This approach has been widely used in literature in sports services, relating it to elements such as perceived quality and satisfaction (Alexandris, Zahariadis, Tsorbatzoudis \& Grouios, 2004; Avourdiadou \& Theodorakis, 2014; Clemes, Brush \& Colins, 2011; Hightower, Brady \& Baker 2002; Howat \& Assaker, 2013; 2016; Yoshida \& James, 2010), or more recently with other elements such as perceived value to take into account monetary and non-monetary sacrifice (Theodorakis et al., 2014), or the organizational culture itself (García-Fernández, Martelo-Landroguez, Vélez-Colon \& Cepeda-Carrión, 2018). This concepts were included in the quality-value-satisfaction-intentions chain (CrespoHervás, Calabuig-Moreno, Prado-Gascó, Añó-Sanz \& NúñezPomar, 2019). In addition, recent studies suggested that the differences in this chain depending on the different business models in the fitness sector, finding the special influence of aspects such as service convenience in low-cost centres (García-Fernández, Gálvez-Ruíz, Fernández-Gavira et al., 2018), the existence or not of lucrative aims in the sports centre (García-Fernández, J., Gálvez-Ruíz, Vélez-Colon, Ortega-Gutiérrez \& Fernández-Gavira, 2018) or limitation of access to certain groups such as those exclusive to men or women (Haro-González, Pérez-Ordás, Grao-Crueces, Nuviala \& Nuviala, 2018). However, fidelity means favourable attitudes and overt commitments on behalf of the consumer, but do not have to correspond with the final decision (Alexandris, Dimitriadis \& Kasiara, 2001; Bodet, 2012). Thus, Sheeran (2002) states in his study that intentions account for only $28 \%$ of the variance in behaviour. This makes it difficult to predict whether a user will leave the sports centre, since cancellation is usually measured with future behavioural intentions and not with respect to current perceptions (Watts, 2012).

On the other hand, loyalty has also been studied through the behavioural approach. This perspective of loyalty refers to repeated purchase of a particular brand. Thus, real behaviours like repetition, frequency or quantity of purchase are used as indicators (Dick \& Basu, 1994; Ferrand, Robinson \& Valette-Florence, 2010; Hallowell, 1996; Zins, 2001). However, this approach does not take into account the emotions and preferences of purchase or the satisfaction with the purchase, not being able to extrapolate the possible causes of loyalty degree (Delgado, 2004; Ishida \& Keith, 2006; Odin, Odin \& Valette-Florence, 2001). We can therefore deduce that there is no clear consensus on the measurement of this concept in literature.

Another aspect that literature has shown interest in is the retention concept (Hallowell, 1996; Watts, 2012), with a greater consensus in its definition and measurement. It is understood as user survival within a sport programme, or as maybe the case, as their permanence in the centre. Thus, retention is generally measured as a dependent binary variable, for example continue or cancel (Bolton, Kannan \& Bramlett, 2000), retention or abandonment (East, Gendall, Hammond \& Lomax, 2005).

Usually, the measurement takes place after a predefined time (for example, 12 months), after which it can be verified whether the user has maintained the purchase pattern with the service provider or has abandoned (Watts, 2012). Several recent studies have researched in depth into these studies, taking advantage of behavioural registration of participants in sport programmes over periods longer than one year, using these variables to be able to create prediction models to be applied to other users (McDonald, Karg \& Leckie 2014; Sperandei et al., 2016). For this type of analysis, different variants of logistic variants are used (León \& Linares, 2014; Rincón, Valero \& Eslava-Schmalbach, 2008). However, these studies are limited to creating the statistical models that estimate the dependent variable with the best fit, discussing the coefficients and weights of each of the factors that make up the regression. This has an important limitation for the real practice, because although they use ex-ante data, it is not possible to know the results until the event has already occurred. Therefore, new studies are necessary to verify the degree of real utility of these systems, demonstrating the long-term viability of the models in new samples and verifying their hypothetical applicability in the day-to-day of the centre, to anticipate users with high risk of drop-out and act in consecuence. 
Therefore, the aim of this study is to design a dropout prediction model for a sport centre based on behaviour recorded by access systems and CRM. For this, an analysis has been replicated in two different sport centres over a year period, applying it again on another sample the following year to achieve a greater consistency in the results. In this way, it will be possible to differentiate those variables easy to follow that can affect the probability of members dropping out of the sports centre.

\section{Method}

\section{Sample and Study Context}

This study has been developed in two sports centres of public ownership with a private management (subcontracted public sport service), situados en el segment de mid-market. Both centres are catalogued as large sized, with more than 5000 different members in the same year. It is important to determine the ownership and characteristics of the centres, since depending on this, the parameters and characteristics that affect the retention and loyalty of clients may vary (GarcíaFernández, Gálvez-Ruíz, Fernández-Gavira et al., 2018 GarcíaFernández, J., Gálvez-Ruíz, Vélez-Colon, et al., 2018). The centres were located in Zaragoza and Tudela (Spain). The centres offer a swimming pool, spa, fitness activities, as well as resistance and cardio training rooms. The members paid a standard price set for the access to all services. The samples in both the centres were composed by all of those who were members of the sports club at some point during 2014 and 2015 with a minimum duration of a month (minimum duration of the type of fees offered in both centres). The data were provided by the management company which permitted their analysis. The methods and procedures conformed to the Declaration of Helsinki and Personal Data Protection Law, and were checked and approved by the Research Committee of the University of A Coruña.

The sample for testing the reproducibility of the model was composed of all sers in 2015, 7076 users in the centre 1 and 910 users in the centre 2. The model was previously designed using as sample all the users of 2014, 6836 users in centre 1 and 5709 users in centre 2 . The drop-out ratio at the end of the year were between $45 \%$ and $50 \%$ in all cases.

\section{Measures}

All monthly values registered were taken into account

\begin{tabular}{|c|c|}
\hline Variables & Definition \\
\hline Age & $\begin{array}{l}\text { Age of the subject in the moment of starting their behaviour registry. } \\
\text { (Years) }\end{array}$ \\
\hline Gender & Indicates the gender of the subject ( $0=$ Male, $1=$ Female $)$ \\
\hline Total changes & $\begin{array}{l}\text { It shows the total changes in membership typology made by the subject } \\
\text { during the analysed year. (Number) }\end{array}$ \\
\hline Maintenance fee & $\begin{array}{l}\text { It registers whether the subject has paid a maintenance fee throughout } \\
\text { 2014. This kind of fee is chosen in summer periods or periods of long } \\
\text { absence. ( } 0=\text { No; } 1=\text { Yes) }\end{array}$ \\
\hline Ex-member & $\begin{array}{l}\text { It indicates whether the subject quitted from the sports centre before being } \\
\text { a new member, during or before the analysed year. }(0=\text { No; } 1=\text { Yes })\end{array}$ \\
\hline Access average & $\begin{array}{l}\text { It tracks the average accesses per month of every subject throughout the } \\
\text { year. (Number) }\end{array}$ \\
\hline $\begin{array}{l}\text { Duration of the } \\
\text { stay }\end{array}$ & The average duration of stay (in minutes) of every access. (Minutes) \\
\hline $\begin{array}{l}\text { Average renewal } \\
\text { period }\end{array}$ & $\begin{array}{l}\text { Days on average included in the advanced payment of every joining fee } \\
\text { paid throughout the year. (Days) }\end{array}$ \\
\hline $\begin{array}{l}\text { Average invested } \\
\text { per month }\end{array}$ & $\begin{array}{l}\text { It shows the average invested per month throughout the analysed year. } \\
\text { (Euros) }\end{array}$ \\
\hline Returned receipts & $\begin{array}{l}\text { It indicates the returned payment receipts per member throughout the } \\
\text { analysed year. (Number) }\end{array}$ \\
\hline $\begin{array}{l}\text { Length of } \\
\text { membership }\end{array}$ & $\begin{array}{l}\text { It quantifies how long a customer has been a member of the sports centre } \\
\text { since they paid their joining fee up to the moment they drop out. (Days) }\end{array}$ \\
\hline
\end{tabular}

using the Deporwin management software used by both centres (T-Innova, Barcelona, Spain). This software includes the historical behaviour and consumer habits of all the users of the centre. The variable selection was made based on the catalogue that the software offers and by consulting literature that determine these variables as behaviour predictors. This information was used to determine the drop-out predicitive models (Table 1 ).

In the first analysis, the monthly and total values registered during the period of 2014 of the selected variables were taken into account for each one of the subjects and as well as their period as a member. Finally, users were coded depending if they had dropped out during the year period or not, and if they had, the time registered up to the moment was counted. For the second analysis, the formula generated from the first analysis was used and was applied to all the records of all the members during 2015, following the same process with the aim of testing the robustness of the models.

\section{Data Analysis}

The purpose in the creation of the predictive model is to develop the regression formula that best fits the levels of sensitivity and specificity intent to decrease the number of variables as far as possible, to facilitate its reproducibility. For this, a simple model will be sought with a reduced number of variables, to be able to apply it to other samples and make it useful for management (Hosmer \& Lemeshow, 2004). Therefore, a manual input logistic regression has been chosen, introducing all the variables initially selected and eliminating one by one the possible combinations until obtaining the best fit.

The estimates are presented including the odds ratio (OR) which can identify the direction of the association, as well as its magnitude of the association. The OR is defined as the ratio of the odds of an event occurring in a group compared to the odds that it happens in a reference group. Thus, in the case of categorical dependent variables, an OR lower than one will indicate a greater chance of it occurring in the reference group, an OR higher than one will indicate more of a chance of it occurring in the group compared to the reference group and an OR equal to one will indicate the event is equally likely in both groups.

Given the size of the sample and the search of a better results interpretation, the scale variables were transformed into exclusive categories, creating a dummy variable. Thus, the variable quartiles were initially selected as cut-off points. In this way, the odds comparison between big groups can be calculated instead of unitary changes, which losses utility if the scales are too broad (Grenn \& Salkind, 2010).

For this, a manual construction of the regression model was performed, initially including all the selected variables. The elimination criteria, variable by variable, was the selection of regression coefficients that presented a likelihood ratio test with no statistical significance (Sanchez-Villegas \& Martínez-Gonzalez, 2006). In the case of transformed variables in quartiles, they were modified in fewer subgroups if any of them lacked significance.

Once the models were defined based on the sample collected in 2014, it was then applied on the records obtained in 2015 on each centre, obtaining the probability of drop out 
of each subject in this new sample. The cut-off point established to consider that a subject will drop out based on the results of the model was a probability of more than 0.5 . In addition, this cut-off point was checked with the optimum point based on the COR curve (Kumar \& Indrayan, 2011). In this way, the relationship of the classifications estimated according to both points and those observed through contingency tables were analysed, thus verifying the discriminant capacity of the model.

\section{Results}

Table 2 shows the estimation made for the model of sports centre 1 , based on the best fit found with the variables collected. The overall model is significant $\left(x^{2}=1466.918\right.$; $p<0.001$ ), and all the variables present a significant association $(p<0.05)$. In the rest of the variables, the condition of exmember and having returned a receipt, double the chances of abandoning the sport centre (OR 2.234; $p<0.001$ for exmembers and OR 2.500; $p<0.001$ in the case of returning a receipt). On the other hand, an increase in the frequency of practice (entrance), expenditure and the average time spent on each entrance, significantly decrease the chances of dropping out $(p<0.05)$. Equally, users over 35 years old and women are significantly more likely to stay within a sport programme $(p<0.05)$. Finally, an increase in antiquity also decreases the chances of abandoning the sport centre, finding the antiquity variables greater than 637 days as the one that most decreases the probability of dropping out (OR $0.180 ; p<0.001$ ). As for fit and model fit, the estimation presents a Cox R ${ }^{2}$ and Snell of 0.195 and a Nagelkerke $\mathrm{R}^{2}$ of 0.260 in both cases far from the unit, which shows the existence of other explanatory variables that are not included in the model. Despite this, the model adequately discriminates $68.6 \%$ of users who continued to practice at the centre and $69.7 \%$ that abandoned (discriminant power of $69.1 \%$ ).

\begin{tabular}{|c|c|c|c|c|c|c|c|}
\hline \multirow{2}{*}{ intuence or cilents habits on th } & \multirow{2}{*}{ B } & \multirow{2}{*}{ E.T. } & \multirow[b]{2}{*}{ Wald } & \multirow[b]{2}{*}{ Sig. } & \multirow{2}{*}{ OR } & \multicolumn{2}{|c|}{ I.C.95\% for OR } \\
\hline & & & & & & Low & High \\
\hline \multicolumn{8}{|l|}{ Not ex-member (base) } \\
\hline Yes ex-member & 0.804 & 0.067 & 144.333 & $\mathrm{p}<0.001$ & 2.234 & 1.960 & 2547 \\
\hline \multicolumn{8}{|l|}{ Accesses ( $<1,33$ accesses) (base) } \\
\hline Accesses (1,34-4,25 accesses) & -0.397 & 0.094 & 17.845 & $\mathrm{p}<0.001$ & 0.672 & 0.559 & 0.808 \\
\hline Accesses (4,26-8 accesses) & -0.567 & 0.107 & 27.961 & $\mathrm{p}<0.001$ & 0.567 & 0.460 & 0.700 \\
\hline Accesses (more than 8 accesses) & -0.780 & 0.113 & 47.667 & $\mathrm{p}<0.001$ & 0.458 & 0.367 & 0.572 \\
\hline \multicolumn{8}{|l|}{ Spent ( $<23,55$ euros) (base) } \\
\hline Spent ( $23,56-31,08$ euros) & -0.189 & 0.079 & 5.650 & 0.017 & 0.828 & 0.709 & 0.967 \\
\hline Spent (31,09-42 euros) & -0.340 & 0.079 & 18.530 & $\mathrm{p}<0.001$ & 0.712 & 0.610 & 0.831 \\
\hline Spent (more than 42 euros) & -0.694 & 0.080 & 75.934 & $\mathrm{p}<0.001$ & 0.500 & 0.427 & 0.584 \\
\hline \multicolumn{8}{|l|}{ Receipts returned (base) } \\
\hline Receipts returned & 0.916 & 0.091 & 102.359 & $\mathrm{p}<0.001$ & 2.500 & 2.093 & 2.986 \\
\hline \multicolumn{8}{|l|}{ Gender male (base) } \\
\hline Gender woman & -0.141 & 0.055 & 6.623 & 0.010 & 0.868 & 0.780 & 0.967 \\
\hline \multicolumn{8}{|l|}{ Antiquity (<168 days) (base) } \\
\hline Antiquity ( $168,01-637$ days) & -0.476 & 0.066 & 51.685 & $\mathrm{p}<0.001$ & 0.621 & 0.546 & 0.707 \\
\hline Antiquity (more than 637 days) & -1.714 & 0.074 & 534.918 & $\mathrm{p}<0.001$ & 0.180 & 0.156 & 0.208 \\
\hline \multicolumn{8}{|l|}{ Stay (<48 minutes) (base) } \\
\hline Stay ( $48,01-81$ minutes) & -0.211 & 0.089 & 5.561 & 0.018 & 0.810 & 0.680 & 0.965 \\
\hline Stay (more than 81 minutes) & -0.347 & 0.097 & 12.889 & $p<0.001$ & 0.707 & 0.585 & 0.854 \\
\hline \multicolumn{8}{|l|}{ Age $<35$ years (base) } \\
\hline Age $(>35$ years) & -0.503 & 0.056 & 81.839 & $\mathrm{p}<0.001$ & 0.605 & 0.542 & 0.674 \\
\hline Constant & 1.619 & 0.093 & 304.051 & $b<0.001$ & & & \\
\hline
\end{tabular}

In terms of its consistency and reproducibility, the formula obtained of the logistic regression is applied to other sample, all of the members of the 2015 year period, obtaining the probability of abandonment for each user. Setting the classification of the user as a drop out from a probability of $0.5,72.7 \%$ can be adequately classified as permanency and $67.5 \%$ as drop outs (discriminant power of $70.1 \%$ ). The optimal cut-off point in this model was of 0.48 , classifying as a drop out those subjects with a greater probability and obtaining a total discriminant power of $69 \%$. Figure 1 presents the ROC curve of the reproducibility of the model in centre 1 .

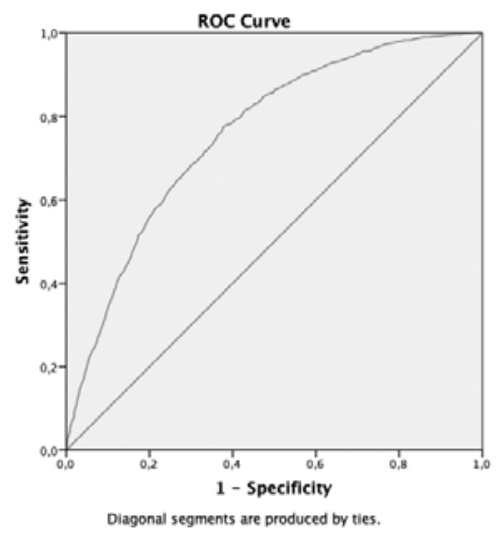

Figure 1. ROC curve for reproducibility of centre 1 .

Following the same process, table 3 shows the results for the model corresponding to centre 2 . The model as a whole is significant $\left(x^{2}=2006.243 ; p<0.001\right)$, and all of the variables presented have a significant association $(p<0.05)$. As with the previous case and with the rest of the variables, the condition of having been an ex-member is the one that most increases the chances of dropping out of the centre, tripling it (OR 3.432; $p<0.001$ ), followed by users that accumulate a returned receipt, with an increase in the chance of drop out of $81 \%$ (OR 1.807; $p<0.001)$. Equally, more accesses and a longer stay in each one of them significantly influence in a lower probability of dropping out $(p<0.05)$. Antiquity is also associated in a significant manner with the permanence at the centre, being the most influent (OR 0.032; $p<0.001$ for users with more than 546 days of antiquity). However, the model presents some discrepancies compared to the other case. Thus, expenditure presents a contrary tendency. The user group that spend the most are significantly more likely to abandon compared to the group that spends less $(p<0.05)$. On the other hand, a new significant variable is observed, in a way that the users with higher periods greater than 30 days of renewal are significantly more likely to abandon(OR 2.863; $p<0.001)$. On the contrary, gender is not included within the variables with a significant association with abandonment or permanence at the centre. As for the fit of the model, the estimation presents values of $\mathrm{R}^{2}$ Cox and Snell of 0.297 and $\mathrm{R}^{2}$ Nagelkerke of 0.397 , also far from the unit. However, the model adequately discriminates $74.5 \%$ of those who stayed

\begin{tabular}{|c|c|c|c|c|c|c|c|}
\hline & B & E.T. & Wald & Sig. & OR & $\begin{array}{l}\text { I.C.95\% } \\
\text { Inferior }\end{array}$ & $\begin{array}{l}\text { for OR } \\
\text { Superior }\end{array}$ \\
\hline \multicolumn{8}{|l|}{ Not ex-member (base) } \\
\hline Yes ex-member & 1.233 & 0.070 & 311.881 & $\mathrm{p}<0.001$ & 3.432 & 2.993 & 3.936 \\
\hline \multicolumn{8}{|l|}{ Renewal period (base) } \\
\hline Renewal period (30 days) & 1.052 & 0.287 & 13.466 & $\mathrm{p}<0.001$ & 2.863 & 1.632 & 5.021 \\
\hline \multicolumn{8}{|l|}{ Antiquity ( $<149$ days) (base) } \\
\hline Antiquity (149,01-302 days) & -1.002 & 0.091 & 122.077 & $\mathrm{p}<0.001$ & 0.367 & 0.307 & 0.438 \\
\hline Antiquity (302,01-546 days) & -2.096 & 0.094 & 492.971 & $\mathrm{p}<0.001$ & 0.123 & 0.102 & 0.148 \\
\hline Antiquity (>546 días) & -3.430 & 0.114 & 901.606 & $\mathrm{p}<0.001$ & 0.032 & 0.026 & 0.041 \\
\hline \multicolumn{8}{|l|}{ No returned reciepts (base) } \\
\hline Yes returned receipts & 0.591 & 0.184 & 10.311 & 0.001 & 1.807 & 1.259 & 2.592 \\
\hline \multicolumn{8}{|l|}{ Accesses ( $<1,91$ accesses) (base) } \\
\hline Accesses (1,92-5,64 accesses) & -0.357 & 0.103 & 12.154 & $\mathrm{p}<0.001$ & 0.699 & 0.572 & 0.855 \\
\hline $\begin{array}{l}\text { Accesses ( }>5,64 \text { accesses) } \\
\text { Stay ( }<46,81 \text { minutes) (base) }\end{array}$ & -0.782 & 0.117 & 44.644 & $\mathrm{p}<0.001$ & 0.457 & 0.364 & 0.575 \\
\hline Stay ( $46,82-83,19$ minutes) & -0.208 & 0.101 & 4.219 & 0.040 & 0.812 & 0.666 & 0.991 \\
\hline Stay (>83,19 minutes) & -0.505 & 0.115 & 19.137 & $\mathrm{p}<0.001$ & 0.604 & 0.481 & 0.757 \\
\hline \multicolumn{8}{|l|}{ Spent ( $<19,87$ euros) (base) } \\
\hline Spent (19,88-34 euros) & 0.886 & 0.083 & 114.017 & $\mathrm{p}<0.001$ & 2.424 & 2.061 & 2.852 \\
\hline Spent ( $>34$ euros) & 0.178 & 0.804 & 4.428 & 0.035 & 1.194 & 1.012 & 1.409 \\
\hline
\end{tabular}


and $73.8 \%$ of those that abandoned (discriminant power of 74.1\%).

The appliance of the obtained formula on the 2015 users, considering the result of drop out from a probability of 0.5 , showed that the model adequately detected $71.6 \%$ of those who stayed at the centre and $67.8 \%$ of those that abandoned (discriminant power of 69.7\%). The optimal cut-off point of this model was of 0.49 , classifying as a drop out those subjects with a superior probability and obtaining a total discriminant power of $70.1 \%$. Figure 2 presents the ROC curve of the reproducibility of the model in centre 2 .

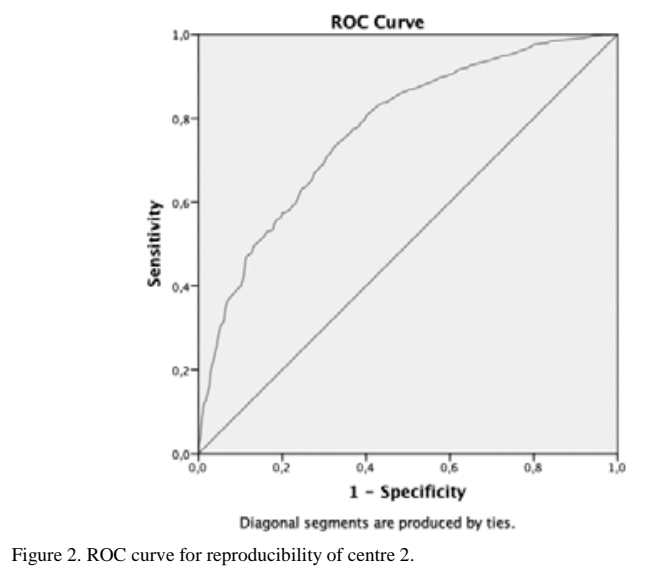

\section{Discussion}

Under the knowledge of the authors, this study is a pioneer in comparing predictive models of member drop outs in fitness and wellness centres over different years. In addition, the variables used are real behaviours registered without the use of questionnaires obtained through internal information sources of daily use of current sport centres. The construction of predictive models using a manual method allowed to reduce the number of variables and categories, maintaining the subset of variables that produce the most information but maintaining or improving discriminant power. In this way, numerous studies analyze the predictive value and the association of each one of these variables independently with dropping out.

Regarding the main purpose of the study, the results demonstrate the consistency of the models when applied to different samples. Specifically, when the predictive formula is applied to the new sample, we can find that both sensitivity and specificity are maintained. Although no studies have been found that confirm the results obtained in the current study, we can establish that the models generated in each of the sports centres are useful and effective, as they maintain their discriminatory power in different samples in different years compared to the sample the model was created on.

However, regression models vary between two centres analyzed, despite being of similar characteristics, being located in a close environment, belonging to the same business segment (mid-market) and using the same data recording system. These findings imply important implications for the professional field since they demonstrate the intra-centre utility in its possible application to anticipate customer losses. However, although the model is consistent in time for the same centre, it is not consistent between different centres, so it is necessary for each sports facility to generate its own model based on the parameters and variables obtained from its system. access control and CRM.

In addition, these results contrast with those obtained by Watts (2012), because it was not possible to achieve consistency in its predictive model when it is applied in another sample from the same sports centre. However, this estimate was made with a attitudinal approach, based on a questionnaire. This study also suggests a superiority of dropout prediction models based on behavioral approach. The relationship between the quality questionnaire results and perceived satisfaction with users future intentions at sports centres has been demonstrated (Alexandris et al., 2004; Avordiaou \& Theodorakis et al., 2014; Howat \& Assaker, 2013). Nonetheless, in real life it is necessary that the centre conduct regular questionnaires with members with two clear negative aspects: the need to interrupt the user and most importantly the inability to have real time control over users obtaining only partial data from members. Therefore, the implicit advantage in the method used is the ease and simplicity to control the variables included, as they represent habits that are registered day to day at the centre. In most of the cases, the centres have comprehensive management software that perform this automatically.

However this method presents some limitations. For example, this study has not differentiated the sample depending on their motivation for attending the fitness centre, in spite of the importance of not abandoning sport practice. Equally, lifestyles can influence on members loyalty in this type of sports centre (Suresh, Ravichandran \& Ganesan, 2011), although in this study they have not been taken into account. We understand that these and other psychological variables like perceived quality, satisfaction or perceived value will modify the final behaviour of the individual. Therefore, existing literature shows that tangible factors like facility quality, equipment and cleanliness or intangible factors like treatment perceived or empathy are clear factors for predicting future intentions related with the individuals satisfaction (Afthinos, Theodorakis \& Nassis, 2005). Therefore, both methods are not exclusive but complementary, although the method proposed in this study may have more limitations in its goodness of fit, it culd be easier to put into practice within the sector.

Secondly, it is also possible to interpret the differences and implications of the explanatory variables included in the models. The variables included in both models were access, stay, antiquity, expenditure, ex-member and receipts returned with the two last variables being the ones with the most importance in both models. The model coincides with other studies in the predictive value of the access variable (Bedford, 2009; Bodet, 2012; Ferrand et al., 2010; Hurley, 2006), antiquity (Ferrand et al., 2010; Watts, 2012), expenditure (Bedford, 2009; McCarthy, 2004) and receipts returned (Chen, Fox, Haase \& Wang, 2006). Point out that neither the change in membership or quota maintenance fee were significant in the final configuration of the models. Therefore, it can be interpreted that loyalty actions based on the offer of economic fees to avoid user drop out may not be effective. Although this study has been carried out in centres located in the so-called mid-market sector, these results are linked to the conclusions 
of García-Fernández, Gálvez-Ruíz, Fernández-Gavira et al. (2018) in the low-cost sector, suggesting that price alone is not a key element in the competition for user loyalty.

The models obtained coincide with those found in other studies in the predictive values of access, antiquity and returned receipts (Chen et al. 2006; Triadó \& Aparicio, 2004). However, the models obtained in each centre are different so it seems that the centre regulations and specific management aspects condition the behaviour of their members. Thus, we find that gender, age or offers of anticipated fees (quarterly, semi-annual, annual) are only significant for one of the models. Therefore, according to the results of this study it is not possible to define a general model for all centres if the aim is to maintain the highest level of goodness of fit possible with the information of their access systems, since depending on their characteristics, it may vary the factors that lead to user loyalty (García-Fernández, Gálvez-Ruíz, Vélez-Colon et al., 2018).

Furthermore, gender has not been significant for predicting member drop outs in other studies (Bedford, 2009; Triadó \& Aparicio, 2004). Park (1996), discarded demographic variables (gender, sex and occupation) as loyalty behavioural predictors. García, Bernal, Lara and Galán (2013) did not find significant gender differences in the study on Andalucian sport service users.

Although older people and anticipated quota fees have been traditionally associated with greater loyalty (Bedford, 2009; Ferrand et al., 2010; IHRSA, 2012; Triadó \& Aparicio, 2004), the inclusion of more variables in the predictive models has led to these two not being significant in drop out prediction. Therefore, it appears that behavioural variables explain the variance of drop out, assuming the differences between ages. Likewise, it seems necessary to analyse in depth the benefits of anticipated fees as there is a great predominance of monthly fees in these centres avoiding in this way longer commitments between the company and its users.

With the methodology and variables selected in this study, a predictive model with a discriminant power near to $70 \%$ is achieved which is determined as optimal according to Steyerberg et al., (2001) and Tenga et al. (2010). The results in specificity and sensitivity are similar to those obtained by Chen et al. (2006) who obtained a predictive effectiveness of $62.5 \%$ for those who drop out (sensitivity) and of $86.6 \%$ for those who do not (specificity). On the other hand, Sperandei et al. (2016) established a predictive drop out model which concludes that member profiles older than 25 years that have never exercised regularly before, are motivated for losing weight and are not motivated for exercising for health, aesthetics or hypertrophy reasons are those who are more likely to drop out each month.

It must be pointed out that although the models have good discrimination power, the goodness of fit was limited, which could indicate the need to include other types of variables such as antiquity, motivation or member lifestyle which explain drop out behavior in the fitness centres. In this regard, our sample is formed by members with different antiquity within in the club, allowing to integrate in the model the different perceptions and uses among experimented and new users. Thus, Watts (2012) showed differences between new and old members, being able to predict drop outs easier in new members than members with more antiquity in the centre. The new members show more intention of cancelling their fee, a lower evaluation of the quality of service, as well as a lower perception of quality-price and intention of use than the members that have belonged to the centre longer. In this manner, the antiquity of the members helps to determine the reasons why members continue or drop out of the centre.

Also Avourdiadou and Theodorakis (2014) find differences in the influence of the quality and satisfaction perceptions on the loyalty between experts and novice members in a fitness centre. The more novice members value as a fundamental aspect the quality perceived, whilst for the more veteran members the general satisfaction is the factor that most influences on the future behaviour of permanence within the centre. In low-cost centres, the study by GarcíaFernández, Gálvez-Ruiz, Fernández-Gavira and Vélez-Colón (2016), shows that the relation between satisfaction, quality and perceived value variables and future intention is stronger in the group that has been a member for less time (less than three months).

\section{Conclusions}

Through the use of sport centre data base, predictive models can be obtained. This allows to identify those subjects that are likely to drop out and those who probably will not, using just behaviour history without taking into account psychological variables. The effectiveness of its application the following year is correct, as it does not show big changes in its power discrimination. In addition, the search for the optimal cut-off point confirms the results obtained finding similar values in specificity and sensitivity. Finally, the present study shows that each sport centre have their own predictive model composed of different variables with different importance within each model, thus each centre must obtain their own model.

The main limitation of this study is that the models present low fit values, therefore in spite of correct discrimination, the inclusion of other variables would improve the models effectiveness. On the other hand, the data collection process of the variables could register computer or manual errors by the centres management.

Future lines of research should evaluate whether the models effectiveness decreases as time passes since its creation. In addition, the identification in this study of two different models allows future research to focus on comparing models from different centres, of different management models and from different cities.

\section{Agradecimientos}

JGU agradece la financiación del «Fondo Europeo de Desarrollo Regional, Programa Operativo de la Región de Castilla-La Mancha» (2018/11744).

\section{References}

Afthinos, Y., Theodorakis, N. D., \& Nassis, P. (2005). Customers' expectations of service in Greek fitness centers: Gender, age, type of sport center, and motivation differences. Managing Service Quality: An International Journal, 15(3), 245-258. 
Alexandris, K., Dimitriadis, N., \& Kasiara, A. (2001). The behavioural consequences of perceived service quality: An exploratory study in the context of private fitness clubs in Greece. European Sport Management Quarterly, 1(4), 280299.

Alexandris, K., Zahariadis, P., Tsorbatzoudis, C., \& Grouios, G. (2004). An empirical investigation of the relationships among service quality, customer satisfaction and psychological commitment in a health club context. European Sport Management Quarterly, 4(1), 36-52.

Avourdiadou, S., \& Theodorakis, N.D. (2014). The development of loyalty among novice and experienced customers of sport and fitness centres. Sport Management Review, 17(4), 419431.

Bedford, P. (2009). Retain \& Gain: Keeping Your Members Engaged. Paper presented in A Global Perspective: Challenges \& Opportunities for Membership Growth \& Retention, San Francisco.

Bodet, G. (2012). Loyalty in Sport Participation Services: An Examination of the Mediating Role of Psychological Commitment. Journal of Sport Management, 26(1), 30-42.

Bolton, R., Kannan, P., \& Bramlett, M. (2000). Implications of loyalty program membership and service experiences for customer retention and value. Journal of the Academy of Marketing Science, 28(1), 95-108.

Brady, M.K., \& Robertson, C.J. (2001). Searching for a consensus on the antecedent role of service quality and satisfaction: an exploratory cross-national study. Journal of Business Research, 51(1), 53-60.

Caruana, A. (2002). Service loyalty: The effects of service quality and the mediating role of customer satisfaction. European Journal of Marketing, 36(7/8), 811-828.

Chen, L.J., Fox, K.R., Haase, A., \& Wang, J.M. (2006). Obesity, fitness and health in Taiwanese children and adolescents. European Journal of Clinical Nutrition, 60(12), 1367.

Clemes, M.D., Brush, G.J., \& Collins, M.J. (2011). Analysing the professional sport experience: A hierarchical approach. Sport Management Review, 14(4), 370-388.

Clemes, M.D., Gan, C., \& Ren, M. (2011). Satisfaction on behavioural intentions in the motel industry: an empirical synthesizing the effects of service quality, value, and customer analysis. Journal of Hospitality and Tourism Research, 35(4), 530-568.

Crespo-Hervás, J., Calabuig-Moreno, F., Prado-Gascó, V., AñóSanz, V., \& Núñez-Pomar, J. (2019). The role of passion in the quality-value-satisfaction-intentions chain: linear models and the QCA approach for athletes. Economic ResearchEkonomska Istraživanja, 32(1), 352-369.

Delgado, E. (2004). Estado actual de la investigación sobre lealtad de marca: una revisión teórica. Revista de Dirección, Organización y Administración de Empresas, 30, 16-24.

Dick, A., \& Basu, K. (1994). Customer loyalty: Toward an integrated conceptual framework. Journal of the academy of marketing science, 22(2), 99-113.

Dimitriades, Z. (2006). Cusotmer satisfaction, loyalty and commitment in service organizations. Management Research News, 29, 782-800.

Dishman, R.K., Sallis, J.F., \& Orenstein, D.R. (1985). The determinants of physical activity and exercise. Public Health Reports, 100(2), 158.

East, R., Gendall, P., Hammond, K., \& Lomax, W. (2005). Consumer loyalty: singular, additive or interactive? Australasian Marketing Journal, 13(2), 10-26.

Estrada-Marcén, N., Gonzalo, G. S., Seral, J. C., Grima, J. S., \& Moliner, A. R. (2019). Perfil profesional de los trabajadores del sector del fitness en la ciudad de Zaragoza. Retos: nuevas tendencias en educación física, deporte y recreación, 35, 185190.

Europe Active. (2015), An overwiew of the European Heath \& Fitness Market Report 2015, Retrieved from http:// www.europeactive.eu/why-ereps

Europe Active (2019). European Health \& Fitness Market Report 2019. Deloitte and Europe Active.

European Comission. (2014). Sport and Physical Activity, Special Eurobarometer 412.

Ferrand, A., Robinson, L., \& Valette-Florence, P. (2010). The intention-to-repurchase paradox: A case of the health and fitness industry. Journal of Sport Management, 24(1), 83-105.

Gallardo, L., Rodríguez-Cañamero, S., Hernando-Barrio, E., \& Peñas, L. (2016). Impacto del comportamiento de los ex-clientes de centros deportivos por tipo de cuota. Revista de Psicología del Deporte, 25(1), 43-46.

García Ferrando, M., \& Llopis, R. (2011). Encuesta sobre los hábitos deportivos en España 2010. Madrid: Centro de Investigaciones sociológicas. CSD.

García, J., Bernal, A., Lara, A., \& Galán, P. (2013). La calidad percibida de servicio y su influencia en la fidelidad de usuarios mayores en centros de fitness públicos. Escritos de Psicología, 6(2), 26-34.

García, J., Gálvez, P., \& Bernal, A. (2015). Diferencias de gasto económico en clientes de fitness low cost según la fidelidad y características sociodemográficas. Paper presented at the VI Congreso Iberoamericano de Economía del Deporte, Murcia.

García-Fernández, J., Gálvez-Ruíz, P., Fernández-Gavira, J., \& Vélez-Colón, L. (2016). A loyalty model according to membership longevity of low-cost fitness center: quality, value, satisfaction, and behavioural intention. Revista de Psicología del Deporte, 25(1), 107-110.

García-Fernández, J., Gálvez-Ruíz, P., Fernández-Gavira, J., VélezColón, L., Pitts, B., \& Bernal-García, A. (2018). The effects of service convenience and perceived quality on perceived value, satisfaction and loyalty in low-cost fitness centers. Sport Management Review, 21(3), 250-262.

García-Fernández, J., Martelo-Landroguez, S., Vélez-Colon, L., \& Cepeda-Carrión, G. (2018). An explanatory and predictive PLSSEM approach to the relationship between organizational culture, organizational performance and customer loyalty: The case of health clubs. Journal of Hospitality and Tourism Technology, 9(3), 438-454.

García-Fernández, J., Gálvez-Ruiz, P., Vélez-Colon, L., OrtegaGutiérrez, J., \& Fernández-Gavira, J. (2018). Exploring fitness centre consumer loyalty: differences of non-profit and lowcost business models in Spain. Economic research-Ekonomska istraživanja, 31(1), 1042-1058.

Gjestvang, C., Stensrud, T., \& Haakstad, L.A. (2019). Are changes in physical fitness, body composition and weight associated with exercise attendance and dropout among fitness club members? Longitudinal prospective study. BMJ open, 9(4), e027987.

Green, S. B., \& Salkind, N. J. (2010). Using SPSS for Windows and Macintosh: Analyzing and understanding data. Prentice Hall Press.

Hallowell, R. (1996). The relationships of customer satisfaction, customer loyalty, and profitability: an empirical study. International Journal of Service Industry Management, 7(4), 27-42.

Haro-González, M., Pérez-Ordás, R., Grao-Cruces, A., Nuviala, R., \& Nuviala, A. (2018). Female users of unisex fitness centres and of fitness centres exclusive for women: satisfaction. International Journal of Sports Marketing and Sponsorship, 19(4), 384-395. 
Hightower, R., Brady, M.K., \& Baker, T.L. (2002). Investigating the role of the physical environment in hedonic service consumption: An exploratory study of sporting events. Journal of Business Research, 55(9), 697-707.

Hillsdon, M. (2001). Winning the retention battle. London: Fitness Industry Association.

Hosmer, D.W., \& Lemeshow, S. (2004). Applied logistic regression. John Wiley \& Sons.

Howat, G., \& Assaker, G. (2013). The hierarchical effects of perceived quality on perceived value, satisfaction, and loyalty: Empirical results from public, outdoor aquatic centres in Australia. Sport Management Review, 16(3), 268-284.

Howat, G., \& Assaker, G. (2016). Outcome quality in participant sport and recreation service quality models: Empirical results from public aquatic centres in Australia. Sport Management Review, 19, 520-535.

Hurley, T. (2004). Internal marketing and the effect on customer retention in the health and fitness industry. Paper presented at the Proceedings of the 12th EASM European Congress on Sport Management, Ghent, Belgium.

IHRSA (2010), The 2010 European Health Club Report. Boston: IHRSA.

IHRSA (2012), IHRSA Member retention report. Boston: IHRSA. IHRSA (2014), The IHRSA Global Report 2014. Boston: IHRSA. IHRSA (2019). The 2019 IHRSA Global Report. Boston: IHRSA.

IHRSA \& Universidad de Alcalá (2018). Informe de mercado de las instalaciones deportivas españolas. Boston: IHRSA.

Ishida, C., \& Keith, J. (2006). Social exchange perspective on consumer loyalty. Marketing, Theory and Applications, 17, 15-16.

Kumar, R., \& Indrayan, A. (2011). Receiver operating characteristic (ROC) curve for medical researchers. Indian Pediatrics, 48(4), 277-287.

Leon, M.A., \& Linares, E.M. (2014). La regresión logística binaria como instrumento para la predicción de deterioro inmunológico a partir de indicadores nutricionales en personas con VIH/ SIDA. Revista Investigacion Operacional, 35(1), 35-48.

Life Fitness (2019). El Mercado del fitness en España 2018. Barcelona: LIFE FITNESS IBERIA

Lutz, R. (1991). The role of attitude theory in marketing. HH. Kassarjian y T.S. Robertson, Perspectives in consumer behavior. Englewood Cliffs: Prentice-Hall International.

MacIntosh, E., \& Law, B. (2015). Should I stay or should I go? Exploring the decision to join, maintain, or cancel a fitness membership. Managing Leisure, 20(3), 191-210.

McCarthy, J. (2004). 10 Characteristics of High-Retention Clubs. Boston: IHRSA.

McDonald, H., Karg, A.J., \& Leckie, C. (2014). Predicting which season ticket holders will renew and which will not. European Sport Management Quarterly, 14(5), 503-520.

Ministerio de Educación Cultura y Deportes (2015). Anuario de Estadísticas Deportivas. Madrid: Secretaria General Tecnica, Subdirección General de Comunicación.

Odin, Y., Odin, N., \& Valette-Florence, P. (2001). Conceptual operarional aspectos of brand loyalty: an empirical investigation. Journal of Bussines Research, 53(2), 75-84.

Oliver, R. L. (1999). Whence consumer loyalty? the Journal of Marketing, 63, 33-44.

Pérez-González, B., García-Unanue, J., Sánchez-Sánchez, J., Sánchez-Burón, A., \& Burillo, P. (2018). Análisis del comportamiento psicoeconómico del consumidor habitual de productos deportivos. Retos: nuevas tendencias en educación física, deporte y recreación, 33, 267-272.

Park, S. H. (1996). Relationships between involvement and attitudinal loyalty constructs in adult fitness programs. Journal of Leisure Research, 28(4), 233-250.

Rincón, D.A., Valero, J. F., \& Eslava-Schmalbach, J. (2008). Cons- trucción y validación de un modelo predictivo de hipotermia intraoperatoria. Revista Española de Anestesiología y Reanimación, 55(7), 401-406.

Rodríguez Cañamero, S., García-Unanue, J., Felipe, J. L., SánchezSánchez, J., \& Gallardo, L. (2019). Why do clients enrol and continue at sports centres?. Sport, Business and Management: An International Journal, in press.

Sanchez-Villegas, A., \& Martínez-González, M. A. (2006). Aspectos avanzados de regresión múltiple. In M. A. Martinez Gonzalez (Ed.), Bioestadística amigable (pp. 753-775). Madrid: Díaz de Santos.

Sheeran, P. (2002). Intention-behavior relations: A conceptual and empirical review. European Review of Social Psychology, 12(1), 1-36.

Söderlund, M. (2006). Measuring customer loyalty with multi item scales: A case for caution. International Journal of Service Industry Management, 17, 76-98.

Sperandei, S., Vieira, M. C., \& Reis, A.C. (2016). Adherence to physical activity in an unsupervised setting: Explanatory variables for high attrition rates among fitness center members. Journal of Science and Medicine in Sport, 19, 916-920.

Steyerberg, E. W., Harrell, F. E., Borsboom, G. J. J. M., Eijkemans, M. J. C., Vergouwe, Y., \& Habbema, J. D. F. (2001). Internal validation of predictive models. Journal of Clinical Epidemiology, 54(8), 774-781.

Suresh, S., Ravichandran, S., \& Ganesan, P. (2011). Understanding wellness center loyalty through lifestyle analysis. Health Marketing Quarterly, 28(1), 16-37.

Tenga, A., Ronglan, L. T., \& Bahr, R. (2010). Measuring the effectiveness of offensive match-play in professional soccer. European Journal of Sport Science, 10(4), 269-277.

Theodorakis, N.D., Howat, G., Ko, Y.J., \& Avourdiadou, S. (2014). A comparison of service evaluation models in the context of sport and fitness centres in Greece. Managing Leisure, 19(1), 18-35.

Triadó, X., \& Aparicio, P. (2004). El tipo de cuota como variable de fidelización de usuarios en Entidades Deportivas: Un reto actual de consecuencias futuras. Investigación y Marketing, 83, 31-38.

Valcarce, M., Cordeiro, C., García-Fernández, J. (2017). Informe centros boutique España. Madrid: Valgo.

Valcarce, M., López, F., García-Fernández, J. (2019). $7^{\circ}$ Informe gimnasios low-cost en España. Madrid: Valgo.

Veiga, O. L., Valcarce-Torrente, M., King-Clavero, A., \& de la Cámara, M.A. (2019). Encuesta Nacional de Tendencias de Fitness en España para 2019. Retos: nuevas tendencias en educación física, deporte y recreación, 35, 341-347.

Veiga, O. L., Valcarce-Torrente, M., King-Clavero, A., \& de la Cámara, M.A. (2018). Encuesta nacional de tendencias de fitness en España para 2018. Retos: nuevas tendencias en educación física, deporte y recreación, 33, 279-285.

Watts, H. (2012). A psychological approach to predicting membership retention in the fitness industry. Worcester: University of Worcester.

Yoshida, M., \& James, J. (2010). Customer satisfaction with game and service experiences: antecedents and consequences. Journal of Sport Management, 24(3), 338-361.

Zeithaml, V., Berry, L., \& Parasuraman, A. (1996). The Behavioral Consequences of Service Quality. Journal of Marketing, 60, 31-46.

Zeithaml, V., Bitner, M.J., \& Gremler, D.D. (2009). Services Marketing: Integrating Customer Focus Across the Firm. New York: Mc Graw Hill.

Zins, A.H. (2001). Relative attitudes and commitment in customer loyalty models: Some experiences in the commercial airline industry. International Journal of Service Industry Management, 12(3), 269-294. 